\title{
SITE-SPECIFIC PROTEST: LIBERATE TATE'S PERFORMANCES AT TATE MODERN
}

\section{Ekin PINAR*}

Received: 18.02.2019; Final Text: 26.11.2019

Keywords: site-specific art; activist performance art; institutional critique; museum space; Liberate Tate.

1. The Freedom of Information Act in UK obliges Tate, a public institution, to disclose this kind of information. Following numerous requests, Tate revealed their censored documents of minutes from an ethics committee meeting on the issue of $\mathrm{BP}$ sponsorship yet refused to release the information on the total amount of money involved in the sponsorship contract. Hidden Figures took place days before a court case that resulted in Tate making the amount public.
In 2014, dozens of performers gathered at the foot of the ramp at Tate Modern's Turbine Hall to protest the long-standing British Petroleum (BP) sponsorship of the museum. After tightly pulling an eight-meter by eightmeter black fabric square by its four edges, some of the group members proceeded to hide below the fabric while also inviting the museum visitors to join them. For more than two hours, the audience at the upper levels of the museum could see a giant black square concealing indiscernible forms underneath. This main performance prop directly referred to the ongoing Malevich: Revolutionary of Russian Art exhibition at Tate Modern whose centerpiece was the artist's well-known Black Square (1913). At the same time, the protest addressed the black rectangles Tate used in their redacted documents to conceal information about the nature and the extent of the BP sponsorship of the institution (Liberate Tate, 2015a, 78-79) (1). Titled Hidden Figures (Figure 1), the protest performance was among a series of "creative disobediences," namely activist guerilla performances unsanctioned by the institution, that the artist collective Liberate Tate staged at Tate institutions between 2010 and 2015 (Evans, 2015, 144) (2). In its interventionist mode and variety of inventive references, Hidden Figures epitomized Liberate Tate's activities that consistently underscored the inseparability of aesthetic, socio-historical, and ecological spheres. In a site-specific mode, the group steadily confronted Tate Modern in a manner that revealed the entangled web of financial, political, and cultural relations of late capitalism that have shaped and maintained the physical space.

A group of artists established Liberate Tate in 2010 in the aftermath of another censorship attempt from Tate. Upon acceptance of an invitation from Tate to run a workshop on art activism that would especially attend to environmental issues, the Laboratory of Insurrectionary Imagination along with artist Amber Hickey received a follow-up notice from the institution asking the workshop organizers to not mention any topics related to Tate's sponsors. In defiance of this hypocritical request, the workshop titled Disobedience Makes History discussed the ethical, aesthetic, and political 
2. Liberate Tate is by no means the first and/ or only activist art collective that stages performances by occupying institutional space. Important and influential precursors include the artist collectives Guerilla Art Action Group that organized a protest at the Museum of Modern Art in New York in 1969 to call for the resignation of Rockefeller family members from the museum's Board of Trustees for their involvement in Vietnam War, as well as ACT UP (AIDS Coalition to Unleash Power) and their performances at various locations including White House, New York Stock Exchange, Saint Patrick's Cathedral (NYC), and Trump Tower (NYC) in the late 1980s and 1990s. Among the more recent collectives that specifically target art institutions are Gulf Labor Artist Coalition (protesting Guggenheim for abusing workers and human rights during the construction of their Abu Dhabi branch) and Decolonize This Place (opposing among other serious issues the displacement of populations and gentrification caused by art institutions). implications of the BP sponsorship of Tate since 1990. Their activities ended with the installment of a banner that read "ART NOT OIL" on the windows of the top floor of Tate Modern (Jordan 2010; Hickey, 2013, 6870; Evans, 2015, 117-8). Following this event, several people involved in the workshop along with a number of other artists and activists formed the protest art collective Liberate Tate. Until the announcement of the end of the sponsorship in 2016, the group staged several performances at Tate Modern and Tate Britain that prioritized site-specific research, attention to history, and the co-existence of various human and non-human temporalities within the exhibition space (such as geological time, duration of natural processes, museum hours, and performance spans). Especially after the Deepwater Horizon oil spill in the Gulf of Mexico (2010) whose environmental effects still continue to this day, the BP direly needed the sponsorship as it affords the corporation the cultural capital and "social license to operate," namely opportunities to clean its image in the public eye and gain access to circles of political elite crowding Tate's exclusive events (Bourdieu and Haacke, 1995, 17-9; Rectanus, 2002; Wu, 2002, 12258; Marriott). Accordingly, in their work, Liberate Tate emphasized the problematic nature of the ties between an art institution that prides itself on its public mission and accessibility and a multinational corporation with a well-documented history of environmental damage, human rights abuses, as well as political support of repressive regimes.

In her influential essay, "The Cultural Logic of the Late Capitalist Museum," Rosalind Krauss $(1990,7)$ notes a significant shift in the conceptualization, functioning, and the image of what she has termed "the late capitalist museum," that has since then turned into a widelyused concept in art history and museum studies. Krauss $(1990,7)$ argues that unlike the modern museum designed around a story of its own linear version of the history of art, contemporary museums "would forego history in the name of a kind of intensity of experience, an aesthetic charge that is not so much temporal (historical) as it is now radically spatial." As Krauss (1990) suggests, this ahistorical spatiality is radically different from the conventional modern museum designed to perpetuate its own linear version of the history of art. A hyperreal space that is no longer mappable, knowable, or fully comprehensible, late capitalist museum becomes the perfect locus for a spectacular aesthetics devoid of any proper historical address, reference, and anchor (Krauss, 1990). In this account, the late capitalist museum emerges as a "non-place," which would severe any ties to history "unless [they have] been transformed into an element of spectacle" (Augé, 1995, 103). Marc Augé $(1995,94)$ coined this term "non-place" in an essay that charts the global homogenization of spaces of "transport, transit, commerce, [and] leisure." For Augé (1995, 75-120), this term constitutes the antithesis of the concept of place to the extent that a non-place lacks any specific identity, predominantly functions as an image rather than an actual lived space, and propagates an experience of anonymity and perpetual present. Even if non-places feature a complex set of individual features such as specific layouts and forms, their spectacular effects materialized in their large-scales, high-tech materials and structures, and streamlined designs absorb these distinctive properties to the point of indistinguishability. As its architecture, urban location, cultural discourse, and complete immersion in neoliberal power relations perfectly encapsulate what Krauss (1990) called the late capitalist museum, Tate Modern and Liberate Tate's performances in this space constitute the specific focus of this essay. Through their performances, what Liberate 
3. For a similar approach to institutional critique especially in its third-generation variants see: Skrebowski, 2013.
Tate achieves is to temporarily transform this non-place dominated by the private financial, political, and cultural interests of corporations into a proper public place of democracy.

Several important studies to-date have emphasized a revived connection between contemporary art and architecture whereby strategies of interaction, intervention, and collaboration bring the two disciplines together (Rendell, 2006; Foster, 2011; Loring Wallace and Wendl, 2013; Bruno, 2014). Yet, these studies neglect to mention the activist performance works that occupy institutional spaces using site-specific methods, even though this vexed area of intersection between art and architecture brings to spotlight certain tensions that exist between the two spheres. The scarce scholarship on Liberate Tate, on the other hand, concentrates solely on the political and ethical ramifications of the sponsorship and the group's protests against it without offering a formal analysis of either the performances or the space of their site-specific acts (Chong, 2013; Mahony, 2014; Rectanus, 2016; Ingram, 2017; Mahony, 2017; Memou, 2017; Motion, 2019). It is quite striking that while this scholarship operates within several disciplines such as museology, geopolitics, finance, political theory, and eco-critique, only Antigoni Memou's article approaches the subject from a primarily art historical perspective (Memou, 2017). While commendable in their interdisciplinary approach, these articles' lack of a comprehensive consideration of the aesthetic principles of Liberate Tate in relation to the highlighted socio-political issues points to a larger problem within the criticism of socially-engaged art.

As art historian Claire Bishop suggests, scholarship focusing on what she calls the "social turn" in art separates political issues from aesthetic, formal, and artistic criteria resulting in an impasse in the possibility of any critical engagement with these art practices other than one on moral grounds (Bishop, 2006, 179-80) (3). Taking heed of Chantal Mouffe's (2008, 11) call to "not see the relation between art and politics in terms of two separately constituted fields, art on one side and politics on the other," I argue that the aesthetic, spatial, political, social, and ecological components of Liberate Tate's works at Tate Modern are inseparable. Accordingly, I offer a formal analysis of the practices of Liberate Tate, such as spatiality, horizontality, use of specific materials, as well as their responses to Tate Modern's curatorial display strategies, to not only reveal the socio-political structuring of the physical space of the museum but also demonstrate how the artist collective reacted to this structuring in their own political mode of aesthetics. The site-specific works of the group attend to and confront the museum space to such an extent that the intervened space presiding over the performative acts, bodies, and props becomes Liberate Tate's principal medium in these performances.

\section{HORIZONTAL ARRANGEMENTS}

When architecture firm Herzog \& de Meuron won the international competition to convert the Bankside Power Station into a modern and contemporary art section for Tate in 1995, the decision stirred a controversy among the prominent members of the world of architecture. Dedicating an entire issue to the competition and the project immediately following the announcement of the winners, ANY: Architecture New York journal spearheaded the criticisms. Variety of articles in the journal not only targeted the winning project but also questioned the logic of holding a competition in the first place for what many considered a mere renovation 
project (Davidson, 1996). For the editor of the journal Cynthia Davidson and Luis Fernández-Galiano $(1996,43-6)$, the problem with Herzog \& de Meuron's submission lied in the project's hesitancy to make a significant gesture that seemingly placed their project in the realm of craftsmanship rather than that of architecture proper. Such an expectation from an architectural project to make a unique and/or expressionistic gestural intervention into the urban fabric certainly dwells on the then-newlyemerging trends in museum design. Since the nineties, in accordance with its new functions as tourist attraction, entertainment center, and consumer hub, the museum began to be defined by its "external wrapper [which] has become more important than its contents," and hence another type of nonplace (Bishop, 2013, 11).

At first glance, it might seem that Herzog \& de Meuron's minimum intervention (save for a lightbox on the roof that runs the entire length of the building) to the exterior envelope of the Bankside Power Station goes against this trend favoring spectacular exteriors in museum design. Yet, what the architects did was to simply turn the concept inside out by rendering the main core of the building its iconic feature and focus of attraction. Both the museum's own accounts as well as Tate's advertisement imagery consistently characterize this main core, Turbine Hall, as the most significant and unique aspect of Tate Modern (Moore, 2000, 9; Serota, 2005, 5; Gayford, 2005, 7; Smith, 2005, 19). In fact, it was largely due to their proposal to keep the scale and volume of Turbine Hall intact that Herzog \& de Meuron won the competition. As the chairman of the advisory board for Tate competition, Richard Burdett, indicated in an interview that from the very outset they expected the contestants to use the Turbine Hall in a significant way in the project even though the competition brief did not specify such a requirement (Davidson, Serota, and Burdett, 1996, 48-9). Among all six contestants, consisting Herzog \& de Meuron, Tadao Ando Architect \& Associates, David Chipperfield Architects, Rafael Moneo, OMA with Richard Gluckman, and Renzo Piano Building Workshop, who entered the second and final stage of the competition, only the winning project offered the possibility of preserving the unity of the Turbine Hall (4).

Herzog \& de Meuron conceived the hall as a covered urban plaza or promenade that would not only visually and physically link the multiple entrances to the more traditionally designed white cube galleries located on the Northern side of the building but also encourage the flux between inside and outside (Herzog, Serota, and Moore, 2000, 38). Some 155 meter in length, 23 meter in width, and 35-meter-high, the hall is a truly vast interior space. By keeping the scale of the original hall that used to house the turbine of the power station, the architects intended the space to be able to accommodate not only large crowds but also the idiosyncrasies of contemporary art pieces that can no longer be categorized under any single medium or standard scale (Herzog and de Meuron, 1996, 54-7). Yet, exactly because of this gigantic scale, for many art critics, Turbine Hall amounts to nothing more than a spectacular vacuum, assigning an impossible task to the artists, namely to fill up this cavernous space (Meyer, 2004, 220-8; Davidts, 2007, 77-92). In turn, all that is left for artists to do is to inflate the kinds of projects they usually create so as to manage and fill up this void (5). Yet, these critics argue, such works only amount to a spectacle devoid of any substance not unlike the space they try to fill in the first place (Meyer, 2004, 220-8; Davidts, 2007, 77-92). I would argue that a prominent visible feature that underscores these operations of filling up the void of the final stage of the competition, see: Moore and Gethings, 1995; Davidson, 1996, 22-51.

5. For a different account that considers what they call the "bigness" of Turbine Hall and its effects on contemporary art in a positive light, see: Baek and Shin, 2015, 49-60. 
Figure 1. Liberate Tate, Hidden Figures, September 2014, performance at Tate Modern (Photo by Martin LeSanto-Smith, 2014)

Figure 2. Liberate Tate, Sunflower, September 2010, performance at Tate Modern (Photo by Jeffrey Blackler, 2010)

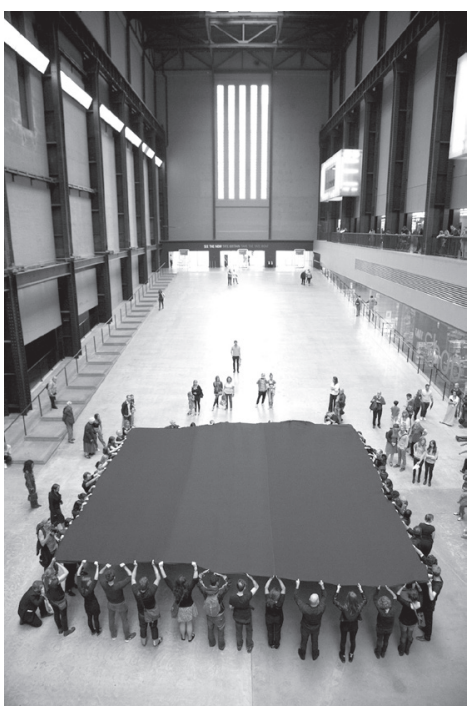

the hall is the vertical exaggeration. Partly because of the north entrance platform that cuts the length of the hall into two, what especially becomes dominant in the hall's scale is indeed its height. Except for a few instances such as Doris Salcedo's Shibboleth (2007) and Tania Bruguera's 10,148, 451 (2018), verticality defines most of the artworks specifically commissioned for Turbine Hall.

Given its status as the building's focal point, it is hardly surprising that Liberate Tate situated almost all of their Tate Modern performances at Turbine Hall. Yet, unlike the majority of the commissioned works exhibited at the hall, their performance pieces take place on and stay close to the ground floor and give visual form to a horizontal form of organization. The main prop of Hidden Figures, whose description opened this essay, for instance, was a black stretched out fabric that the performers held parallel to the floor (Figure 1). In her book Artwashing, one of the members of Liberate Tate, Mel Evans $(2015,91)$ ascribes a quasi-religious authority to Turbine Hall whose "ceiling ... reaches heavenly heights in cathedralesque magnificence," identifying this quality as one of the main attractions for corporate public relations departments. It is therefore possible to say that the performance carefully considered the vertical emphasis in the organization of Turbine Hall and responded to it with a horizontal arrangement, inasmuch as the protest piece oriented itself mainly to the foyers and the platform above so as to be read as a giant black mark of censorship glossing over the figures below the fabric.

A similar horizontal emphasis is also at play in Sunflower (2010), in which forty performers stepped on black oil paint tubes to form a giant sunflower pattern on the floor of the hall (Figure 2). Focusing the attention on the ground, these performances critically negate the spectacular rhetoric of the building that finds its most fundamental expression in the vertical expanse of the Turbine Hall. Even The Gift (2012), a 16.5 meter wind turbine blade carried by performers to Tate Modern, was laid down horizontally on the floor (Figure 3). The obvious practical difficulties of setting upright such a heavy piece aside, the selection in the first place of a vertically commandeering object to be laid flat still accords with the dominant aesthetic organization of the group. As Hito Steyerl $(2012,78)$, in her discussion of the two levels of articulation in any protest, states:

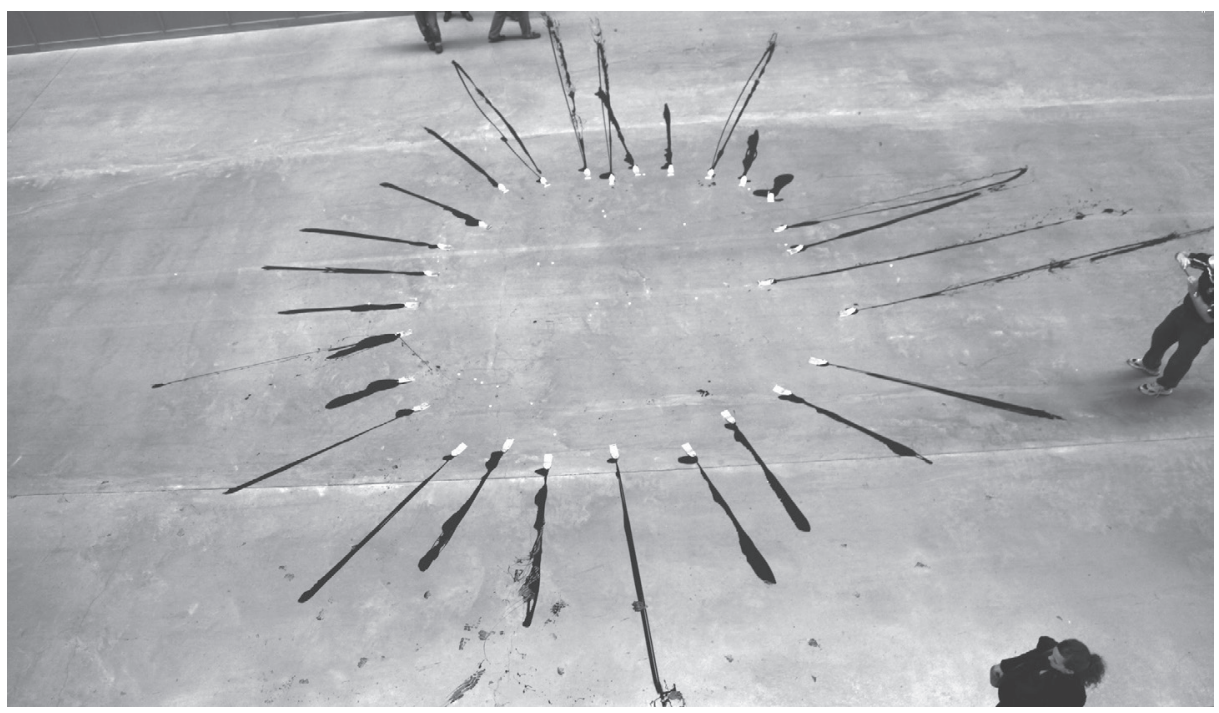


Figure 3. Liberate Tate, The Gift, July 2012, performance at Tate Modern (Photo by Martin LeSanto-Smith, 2012)
6. Also see: Ryan, 2000, 30. Ryan indicates that details such as MDF panels and castiron air vents were used to contribute to the industrial aesthetic.

7. For two excellent discussions on the intricate ties between this industrial aesthetic and post-industrial economies, see: Bishop, 2004, 51-3; Foster, 2015, 25-6.

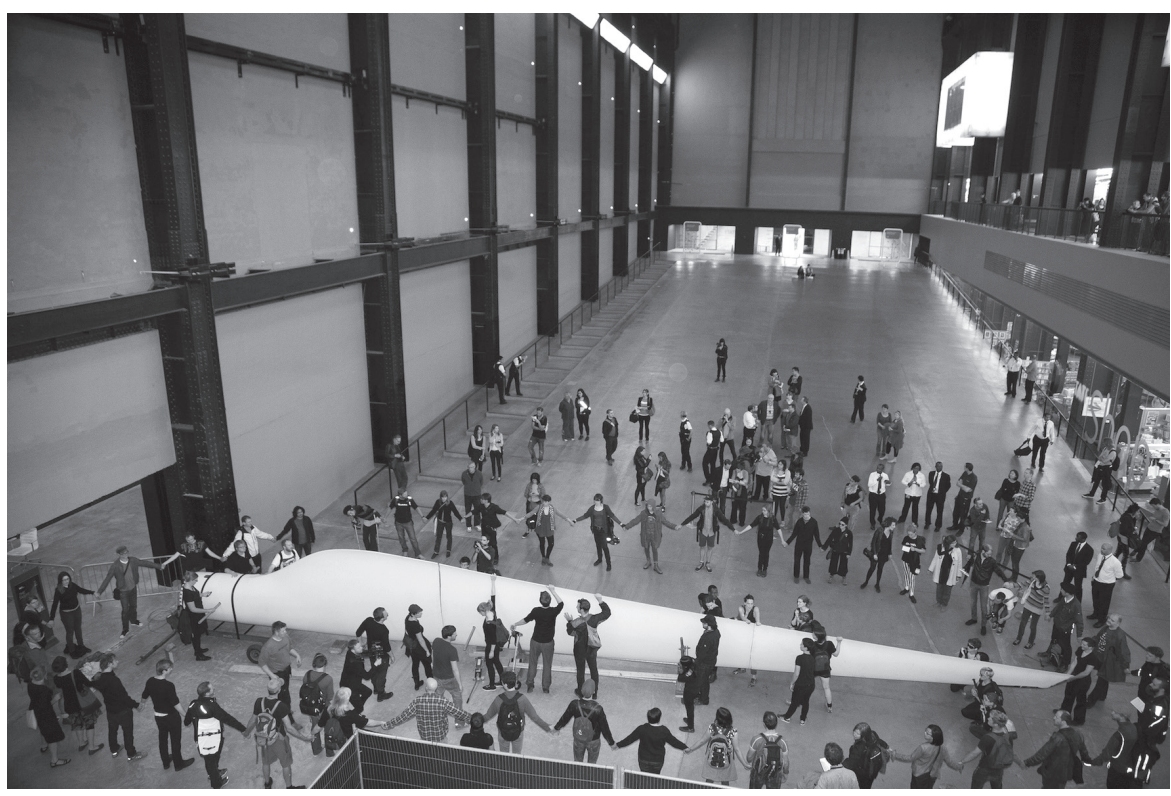

"On one level, the articulation entails finding a language for protest, the vocalization, the verbalization, or the visualization of political protest. On another level, however, the articulation also shapes the structure or internal organization of protest movements." In Liberate Tate's case, the visually horizontal articulation of the protest materializes the organizational form of the group as a heterogenous yet equalitarian network that opposes the top down capture of the Turbine Hall by the corporate rhetoric.

\section{MATERIALS}

During the ongoing conversations concerning the relocation of the modern and contemporary section of Tate's collection in a separate building and whether the conversion of Bankside Power Station would be a viable option for the purpose, Nicolas Serota, the director of Tate, along with management consultants, sent out a questionnaire to a global selection of well-known artists to get the measure of their preferences regarding exhibition spaces (Davidts, 2007, 82). The majority of the artists who responded to the survey indicated that they opted for exhibition spaces converted from already existing structures, a finding that encouraged the institution toward the option they already favored: renovation of Bankside Power Station (Dean, 2009, 133). In their official accounts, Tate museum announced that, besides the obvious economic advantages, their choice to convert a defunct industrial structure rather than building from scratch followed a trend in museum and gallery design toward an "art factory" or "industrial shed" concept (Herzog, Serota, and Moore, 2000, 44; Moore, 2000 , 11) (6). A visible offshoot of the new tendency in museum architecture since the late nineties, such spaces differed from the pristine, supposedly neutral aesthetics of the white cube and at least initially invited open-ended artworks that support a work-in-progress aesthetics (7).

Both Serota and Burdett indicated in an interview with Davidson (1996, 46-8) that the big scale of contemporary artworks as well as their aesthetic tendencies were influential in their choice of an existing industrial building. The architects themselves announced their intention to turn the Turbine Hall into a "galleria with a unique industrial character" in their proposal 
8. To that end, I do not agree with Rowan Moore and Wouter Davidts who both argue that it is impossible to tell at Tate Modern where the old building ends and the new one starts. See: Moore, 2000, 8; Davidts, 2016, 206. for the final stage of Tate Modern competition (Herzog and de Meuron, 1996, 57). Yet, in its ultimate execution, Tate Modern's galleries emerged as white cubes with a new and pristine look, whereas the façade of the building sustained its earlier appearance and industrial aesthetics to a great extent (8). As for Turbine Hall, the clean, finished look of almost all its elements, such as the North entrance platform and its black staircase, along with the gallery foyers that function as light boxes overlooking the hall, does not allow the aesthetics of the space register exactly as workshop-like or industrial. False columns of steel covered with shiny black paint conceals the actual steel structure skeleton from the first phase of the building, a clean coat of gray paint coats the brick walls, and even the concrete floor shines with a clean polish. This polished, pristine look results in a neutral aesthetics rather than an industrial one. In fact, as many architecture critics argue, neutrality constitutes one of the primary defining features of Herzog \& de Meuron's general aesthetic approach to architecture (Davidson and Fernández-Galiano, 1996, 43; Self, 2014, 91).

The effects of such neutrality of the interior spaces of Tate Modern including Turbine Hall is twofold. First, the pristine, sterile aesthetics obscures the history of the building as a power plant. In this respect, the neutrality of the hall perfectly accords with the ahistoricity of the late capitalist museum that Krauss underlines and criticizes (Krauss, 1990, 7). Second, this neutrality has wider ramifications in relation to the claims of modern museum spaces, or white cubes, to universality and timelessness. While a product of its own socio-historical context of the twentieth century, the neutral appearance of the white cube sustains a non-interventionist narrative whereby the exhibition space does not interfere with the perception and interpretation of the artworks on display. Reacting to such a conspicuous construct, a mode of critique against this rhetoric of the art institution, widely known as Institutional Critique, emerged in the late sixties (Alberro and Stimson, 2009; Raunig and Ray, 2009). An impulse to reveal the social, political, and economic forces structuring the white cube informed the work of many artists like Hans Haacke, Marcel Broodthaers, Daniel Buren in the seventies and Andrea Fraser and Fred Wilson in the nineties (Alberro and Stimson, 2009; Raunig and Ray, 2009). These artists questioned the power structures that are at work at the supposedly neutral museum and gallery spaces and revealed the impossibility of the autonomy of the aesthetic sphere. In their critical performances at Tate institutions, Liberate Tate follows in the footsteps of Institutional Critique and its sitespecific mode of production, yet unlike the majority of earlier artworks in this tradition, their pieces are unsanctioned by the institutions they address.

Even though, in its sheer scale, structure, and color preferences, Turbine Hall's appearance differs from the conventional white cube galleries, its style and choice of materials still materialize a rhetoric of neutrality. The creative interventions of Liberate Tate subvert this neutrality by introducing messy materials, such as fake oil (molasses), ice, interruptive sounds, and a wind turbine, into the museum space (Liberate Tate, 2015b, 417). "Deliberately abject and sometimes foul," maintains Liberate Tate, "our work is the shadow of an industry the reality of which arts organizations do not want to see on their doorstep" (Platform, Art not Oil, Liberate Tate, 2011, 87). During the performance of Sunflower (2010), for instance, forty artists formed a circle in the Turbine Hall and sequentially stepped on BP branded oil paint tubes to splash the pitch-black substance onto the floor (Figure 2). The configuration of the black stains resembled 
a sunflower as well as the helios logo of the BP brand and referenced in advance the upcoming Turbine Hall exhibition of Sunflower Seeds by Ai Weiwei (2010). While the corporation's logo in vivid green and yellow cynically alludes to natural resources, the black material Liberate Tate used in their performance referred to the recent oil spill at the Deepwater Horizon disaster and its catastrophic effects on the environment. The visceral, tangible quality of the material albeit temporarily tainted the polished surface of the floor of Turbine Hall bringing a seemingly distant disaster and its relationship with the museum to the attention of audiences. Accordingly, this intervention into Tate Modern subverted the convoluted narrative of an autonomous aesthetic realm and mapped out the museum's place within a much larger network of social and financial relations.

Liberate Tate's sound pieces such as Tate à Tate (2012) and All Rise (2013), similarly expose the otherwise hidden connections between the aesthetic sphere and the intricate global webs of neoliberal exploitation. For Tate $\grave{a}$ Tate, the group produced an alternative free audio guide for Tate, one which aids the audience in making connections between the artworks on display and BP's exploits elsewhere. Textual content of the audio guide, therefore, relocated the museum space within the context of the ongoing environmental destruction and human rights abuses, one of the main culprits of which was sponsoring Tate. Among many others, the stories of Louisiana fisheries effected by the Deepwater disaster, of indigenous peoples of Canada protesting tar sand operations threatening the boreal forests and their livelihood, and of Colombian farmers who got killed by the BP-financed paratroops interrupt the dominant account of the museum and its sponsor. Doing so, Liberate Tate (2012d, 138) aims to "complicate the presence of BP in the gallery, ... asking participants to enact a gently rebellious role." Likewise, All Rise interlinked the museum space to other locations around the world in order to implicate the roles the corporatesponsored museum plays within seemingly distant events. Over the course of seven days, several performers at Turbine Hall whispered the court transcripts of the BP Gulf of Mexico trial at New Orleans. Equipped with wide angle cameras set at eye-level, the performers, in turn, live-streamed on a web page their performances set against Tate Modern (Liberate Tate, 2015b, 417).

\section{NATURE DECOMMODIFIED}

Liberate Tate's practice of placing at Tate institutions materials foreign to the neutrality discourse of the museum has wider implications in terms of the institution's perspective on history and nature. Just as the architecture of the building, the way Tate Modern has curated its permanent collection of modern and contemporary art since its opening in 2000 has been a subject of controversy (Nixon et al., 2001, 3-25; Demos, 2009a, 256-65; Enwezor, 2008, 207-29). Instead of organizing the artworks in a conventional chronological order as in the case of the quintessential display of twentieth century art at the Museum of Modern Art in New York, Tate curators opted for a thematic arrangement. The four themes that juxtapose artworks in an ahistorical mode consist of Still Life/Object/Real Life, Nude/Action/Body, History/Memory/Society, and Landscape/Matter/ Environment. While this thematic ordering makes interesting, albeit in some cases unproductive and gimmicky, associations between the works on display, I would like to suggest that the fundamental problem within this topical curation lies in the primarily Western distinctions the curatorial 
themes intimate between subject (human) and object (non-human) as well as nature and culture. Ordering the world from an anthropocentric perspective, these themes suggest a romantic separation between nature and culture that has fueled the expropriation and commodification of the environment and its resources. In other words, such separation between nature and culture is deeply problematic to the extent that it generates an understanding of nature as a pure, static entity fixed in its own place. Objectification of nature as such, in turn, enables capitalist forces to fully exploit the environmental resources for financial benefit (Demos, 2009b, 20-25; Lam et al., 2013, 145-46). As Dipesh Chakrabarty's (2009, 201-07) first thesis on "the climate of history" suggests, it is no longer possible to maintain "the age-old humanist distinction between natural history and human history," especially in the age of Anthropocene.

In direct opposition against this traditional distinction between nature and culture, Liberate Tate addresses nature as a "contingent assemblage of biological, technological, economic and governmental concerns," as Yates McKee $(2007,561)$ would put it. As part of the performance entitled Floe Piece (2012), for instance, four artists carried on a stretcher a block of Arctic ice from the Occupy London site in the vicinity of St. Paul's Cathedral across the Millennium Bridge to Tate Modern's Turbine Hall. Their use of a stretcher pointed to the direness and the emergency of the issue of global warming. Centered around the melting of ice, the performance simultaneously interrupted the dominant rhetoric of the museum that separates nature from culture by making visible the events at an apparently distant geography. This gesture, therefore, disclosed the intricate relationship between the supposedly autonomous cultural sphere of the museum and the effects of global warming stimulated by the financial interests of fuel-industries on the Arctic Pole. As Liberate Tate asserts (Lam et al., 2013, 145):

"Our choice to use or allude to certain raw materials could be said to ... [play] a key role, almost like a performer itself. While the presence of these materials may suggest 'the natural', it also highlights how that presence is a performance, similar to how the brick of a building is considered natural. The work functions along the lines of Donna Haraway's cyborgs; they remain referential to the natural and the synthetic in one continuous spectrum, rather than as opposing forces."

As their emphasis on this hybrid character of materials attests, the use of ice underscores the indivisible character of nature and culture inasmuch as it becomes a performative element itself within the borders of the museum.

Floe Piece implicitly references a series of post-war era artworks that have made processes of melting or condensation their primary medium and material. In his happening Fluids (1967) that took place in Pasadena and Los Angeles, Allan Kaprow, for instance, asked the participants to build walls out of big blocks of ice. In defiance of the commodification of artworks, Kaprow used against itself the economic principle of built-in obsolescence that normally keeps the commodity flow steady. In Kaprow's happening, the built-in obsolescence of the material, namely melting ice, prevented it from becoming a commodity in the art market in the first place. In a similar vein that subverts the workings of the art market by questioning the value of objects, David Hammons put on sale varying sizes of snowballs among other street vendors in front of Cooper Union in New York City, for his work titled Bliz-aard Ball Sale (1983) (9). Hans Haacke's Condensation Cube (1963-65), on the other hand, used the processes of vaporization and condensation to index the impact of the exhibition space on the artwork.
9. For further discussion on the elusive Hammons' performance itself see: Filipovic 2017. 
Figure 4. Liberate Tate, Time Piece, June 2015, performance at Tate Modern (Photo by Martin LeSanto-Smith, 2015)

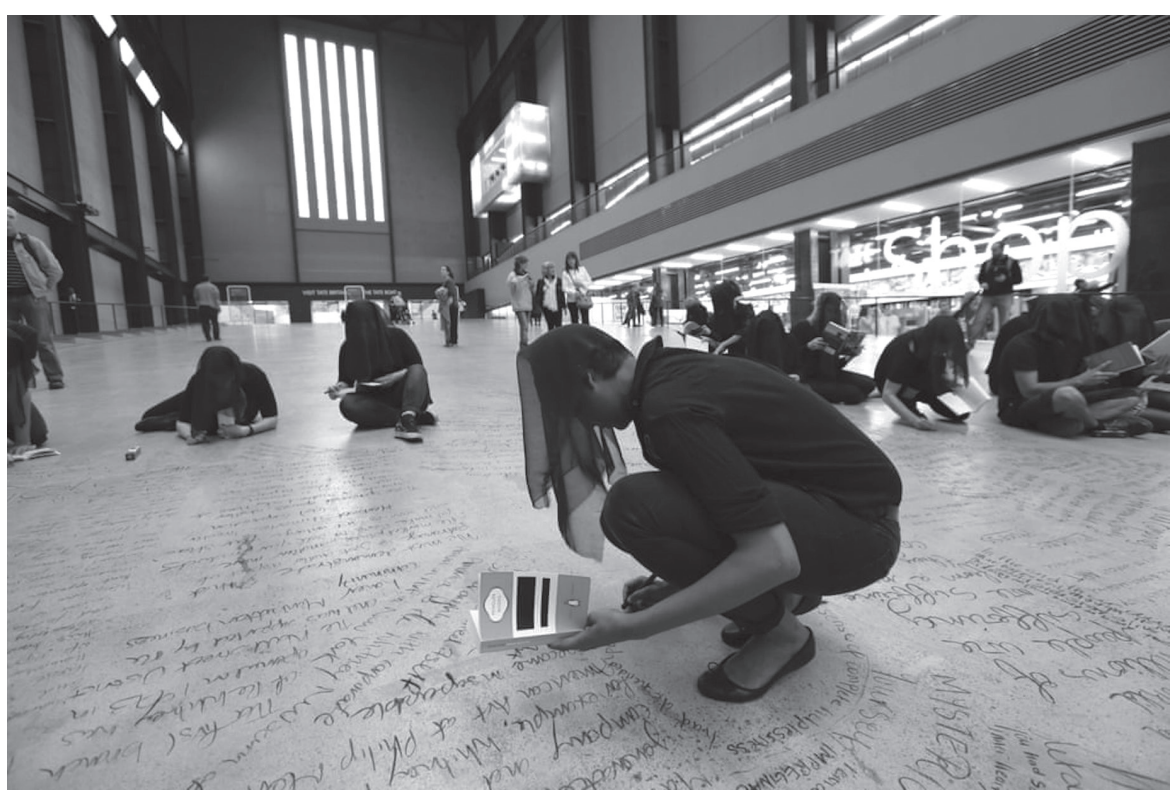

As these natural processes constantly change the appearance of a plexiglass cube with a small amount of water in it, the climate-controlled environment of the gallery and its function of the conservation of artworks to maintain their market value become fully visible (10). While directly related to these pieces, Liberate Tate's Floe Piece simultaneously brings to our attention how, due to global warming and climate change, economic interests and global operations of multinational corporations are now directly implicated in a formerly mundane process, that is the melting of ice.

Liberate Tate's attention to history is not limited to the sphere of the art world. As exemplified by their work Time Piece (2015), their interest in various kinds of temporalities materializes a non-anthropomorphic sense of history (Figure 4). During a 25-hour long performance that defied the regular museum hours, seventy-five performers wrote on the floor of Turbine Hall several texts on activism, oil industry, global warming, art, and architecture. Significantly, one of the texts was taken from Building Tate Modern: Herzog \& De Meuron Transforming Giles Gilbert Scott (2000), a gesture that demonstrates the site-specific research interests of the group. The collective set the performance between the two high tides on the Thames River and the charcoal-inscribed texts followed flowing wavy patterns alluding to the tidal waves (Liberate Tate, 2015d):

"The performance explores lunar time, tidal time, ecological time, geological time and all the ways in which we are running out of time: from climate change to gallery opening hours; from the anthropocene to the beginning of the end of oil sponsorship of the arts."

Liberate Tate's efforts to put the ahistorical space of Tate Modern in dialogue with history also figures in their work, The Gift (Figure 3). Bringing a wind turbine to the Turbine Hall references the building's own history as a power plant. In offering a cleaner energy resource to the institution as a gift, the artists explore and engage with the entire history of the site from when it stored large quantities of oil to generate electric power to its contemporary financial ties to the fuel industry.
10. For an insightful reading of Haacke's Condensation Cube from an eco-aesthetic perspective see: Skrebowski, 2013. 
11. For Herzog \& de Meuron's architectural drawings that show Whiteread's House in Turbine Hall, see: Moore and Ryan, 2000. While the plans and perspectival drawing in this publication shows House within the Turbine Hall, the perspectival drawing from the final stage of the competition shows Whiteread's Ghost in the same location, suggesting that the earlier mistake was corrected in the ultimate drawings. Since Ghost was enlarged to the size of House in the said drawing, Wouter Davidts perceives this mistake as anticipating the blown-up scales of Turbine Hall installations. See: Davidts, 2016, 205.

12. While both Mahony and Memou suggest that Liberate Tate transforms the space into a public one, neither analyzes this transformation in visual terms. What interests me here is how the dominant order visually figures in the space and how Mouffe's antagonism and conflict becomes a vital part of the audio-visual aesthetics of Liberate Tate in their challenge to this dominant order. See: Mahony, 2014; Memou, 2017.

\section{CONCLUSION}

Having transformed the site of a power plant of restricted entry into a public institution that allows free access to its permanent collections, Tate Modern considers itself a public space and Turbine Hall "a huge free gift to the public" (Moore, 2000, 30). The architecture of the building itself dwelled upon this claim to publicness and accessibility. A transitional space that not only links entrances to the building and the galleries but also bridges between North and South London, Turbine Hall has definitely acted as a passage connecting the flow of people approaching the building via Millennium Bridge from the North of the Thames to the wider Bankside area on the South. A wide ramp that marks the West façade as the main entrance and continues for about one third of the length of the Turbine Hall strengthens the building's efforts to stimulate the flow of people. The hall also serves as a hang-out hub for crowds since its opening in 2000. Significantly, in the preliminary drawings of the Turbine Hall, Herzog \& de Meuron included Rachel Whiteread's House (1993) as an example for the kind of work that could be exhibited in this space (11). To execute House, Whiteread cast out of concrete the interior of a large Victorian House in East London that was scheduled to be demolished as part of a regeneration process in the area. The work temporarily stood in a park nearby as an anti-monument, a ghostly presence, and a reminder of gentrification and its erasure of social memory before it was subject to censorship and demolition itself (Saltzman, 2006, 80-9). Such reference to House appears ironic when we consider that the urban regeneration project of Bankside Area in Southwark, London, in which Tate Modern played a vital part, garnered wide-spread criticism due to its gentrification effects (Miles, 2000, 61; Dean, 2014, 146-90). With this in mind, it is still open to debate whether the "public" that is addressed by Tate is inclusive of lower-income and working classes who had to leave the area due to both the rent rise in formerly-affordable housing complexes and the evictions preceding demolitions.

Meanwhile, in museum's own accounts on the building's impact on the Bankside neighborhood, the significant rise in property values in the area figures as a positive development (Travers, 2005, 23; Hyslop, 2012, 158). This logic parallels the institution's unquestioning acceptance of funds from a multinational corporation that values financial profit over human and non-human life and the environment. To the extent that such private interests undermine the public character of the museum space, Tate Modern surrenders to a neoliberal "rationality extending a specific formulation of economic values, practices, and metrics to every dimension of human life" (Brown, 2015, 30). Through their arrangement mode, choice of materials, and approach to the concepts of nature and history, Liberate Tate's site-specific performances challenge this hegemonic neoliberal rhetoric of Tate Modern (12).

One of the seventy texts Liberate Tate members inscribed on the floor of Turbine Hall for Time Piece was Mouffe's 2013 book, Agonistics: Thinking the World Politically. In this book, Mouffe (2013) suggests that the possibility of public space relies on its accommodation of a plural democracy that allows for conflict and disagreement. In Mouffe's agonistic model of public space, dissensus and antagonism discloses the hegemonic ways in which the space is structured $(2013,91-4)$. The contrasts and conflicts Liberate Tate introduces against the visual discourse of Turbine Hall reveals, in turn, the dominant political, financial, and social order of the space. Their agonistic 
intervention temporarily transforms the museum into a truly public space whereby the real dynamics of the space is revealed and contested. It is to this extent that Liberate Tate's politically structured aesthetics is powerfully spatial.

\section{BIBLIOGRAPHY}

AUGÉ, M. (1995) Non-Places: Introduction to an Anthropology of Supermodernity, trans. J. Howe (1995), Verso, London and New York.

ALBERRO, A., STIMSON, B., eds. (2009) Institutional Critique: An Anthology of Artists' Writings, The MIT Press, Cambridge and London.

BAEK, J., SHIN, Y-J. (2015) Accidental yet Transformative: Site-specificity of the Turbine Hall of Tate Modern, Architectural Research Quarterly 19(1) 49-60.

BISHOP, C. (2004) Antagonism and Relational Aesthetics, October 110(Fall) 51-79.

BISHOP, C. (2006) The Social Turn: Collaboration and its Discontents, Artforum 44(6) 178-83.

BISHOP, C. (2013) Radical Museology: or, What's 'Contemporary' in Museums of Contemporary Art? Koenig Books, London.

BOURDIEU, P., HAACKE, H. (1995) Free Exchange, Polity Press, Cambridge and Oxford.

BROWN, W. (2015) Undoing the Demos: Neoliberalism's Stealth Revolutions, Zone Books, New York.

BRUGUERA, T. (2018) 10,148, 451.

BRUNO, G. (2014) Surface: Matters of Aesthetics, Materiality, and Media, The University of Chicago Press, Chicago and London.

CHAKRABARTY, D. (2009) The Climate of History: Four Theses, Critical Inquiry 35(2) 197-222.

CHONG, D. (2013) Institutions Trust Institutions Critiques by Artists of the BP/Tate Sponsorship, Journal of Macromarketing 33(2) 104-16.

DAVIDSON, C., ed. (1996) Tate Frames Architecture: Cashes in on Culture Lottery!, ANY: Architecture New York 13.

DAVIDSON, C., FERNÁNDEZ-GALIANO, L. (1996) Exquisite Corpse, ANY: Architecture New York 13 40-7.

DAVIDSON, C., SEROTA, N., BURDETT, R. (1996) Interview with Serota and Burdett, ANY: Architecture New York 13 23-58.

DAVIDTS, W. (2007) The Vast and the Void: On Tate Modern's Turbine Hall and 'The Unilever Series', Footprint 1(1) 77-92.

DAVIDTS, W. (2016) A Grey Universe: Tate Modern's Turbine Hall and The Unilever Series, Sculpture and the Museum, ed. C. Marshall, Routledge, London and New York; 197-216.

DEAN, C. (2009) From Flash Art to Flash Mob: How have New Gallery Spaces Informed the Nature of Contemporary Display?, Curating Architecture and the City, eds. S. Chaplin and A. Stara, Routledge, London and New York; 129-42. 
DEAN, C. (2014) Establishing the Tate Modern Cultural Quarter: Social and Cultural Regeneration through Art and Architecture, unpublished Ph.D. Dissertation, London School of Economics, London.

DEMOS, TJ. (2009a) The Tate Effect, The Global Art World: Audiences, Markets, Museums, vol. 2, eds. H. Belting, A. Buddensieg, and P. Weibel, Hatje Kantz, Ostfildern; 256-65.

DEMOS, TJ. (2009b) The Politics of Sustainability: Contemporary Art and Ecology, Radical Nature: Art and Architecture for a Changing Planet 1969-2009, ed. F. Manacorda, Barbican Art Gallery, London; 16-30.

ENWEZOR, O. (2008) The Post-Colonial Constellation, Antinomies of Art and Culture: Modernity, Postmodernity, Contemporaneity, eds. T. Smith, O. Enwezor, and N. Condee, Duke University Press, Durham and London; 207-29.

EVANS, M. (2015) Artwash: Big Oil and the Arts, Pluto Press, London.

FILIPOVIC, E. (2017) David Hammons: Bliz-aard Ball Sale, Afterall Books/One Work and The MIT Press, Cambridge and London.

FOSTER, H. (2011) The Art-Architecture Complex, Verso, London and New York.

FOSTER, H. (2015) After the White Cube, London Review of Books 37(6) 25-6.

GAYFORD, M. (2005) A New Space for A New Art, Tate Modern: The First Five Years, ed. N. Serota, Tate Publishing, London; 7-12.

HAACKE, H. (1963-65) Condensation Cube.

HAMMONS, D. (1983) Bliz-aard Ball Sale.

HERZOG, J., de MEURON, P. (1996) Herzog \& de Meuron (Proposal for the final stage of Tate Modern competition), ANY: Architecture New York 13 54-7.

HERZOG, J., SEROTA, N., MOORE, R. (2000) Conversation, August 1999, Building Tate Modern: Herzog \& De Meuron Transforming Giles Gilbert Scott, eds. R. Moore and R. Ryan, Tate Gallery, London; 37-57.

HICKEY, A. (2013) Beyond Reflection: Radical Pedagogy and the Ethics of Art Sponsorship, OnCurating 20 68-72.

HYSLOP, D. (2012) Culture, Regeneration, and Community: Reinventing the City, Gateways: International Journal of Community Research and Engagement 5(1) 152-65.

INGRAM, A. (2017) Art, Geopolitics, and Metapolitics at Tate Galleries London, Geopolitics 22(3) 719-39.

JORDAN, J. (2010) On Refusing to Pretend to Do Politics in a Museum, Art Monthly 33435.

KAPROW, A. (1967) Fluids.

KRAUSS, R. (1990) The Cultural Logic of the Late Capitalist Museum, October 54(Fall) 3-17.

LAM, S., NGCOBO, G., PERSEKIAN, J., THOMPSON, N., WITZKE, A.S., LIBERATE TATE (2013) Art, Ecology and Institutions: A Conversation with Artists and Curators, Third Text 27(1) 141-50.

LIBERATE TATE (2010) Sunflower. 
LIBERATE TATE (2012a) Floe Piece.

LIBERATE TATE (2012b) Tate à Tate.

LIBERATE TATE (2012c) The Gift.

LIBERATE TATE (2012d) Disobedience as Performance, Performance Research 17(4) 135-40.

LIBERATE TATE (2013) All Rise.

LIBERATE TATE (2015a) Confronting the Institution in Performance: Liberate Tate's Hidden Figures, Performance Research 20(4) 78-84.

LIBERATE TATE (2015b) Notes on All Rise, Contemporary Theatre Review 25(3) 417.

LIBERATE TATE (2015c) Time Piece.

LIBERATE TATE (2015d) Time Piece. [http://www.liberatetate.org.uk/ performances/time-piece/] Access Date (06.02.2019).

LORING WALLACE, I., WENDL, N., eds. (2013) Contemporary Art about Architecture: A Strange Utility, Ashgate, Surrey and Burlington.

MAHONY, E. (2014) Locating Simon Critchley's 'Interstitial Distance' in the Practices of The Freee Art Collective and Liberate Tate, Art $\mathcal{E}$ the Public Sphere 3(1) 9-30.

MAHONY, E. (2017) Opening Spaces of Resistance in the Corporatized Cultural Institution: Liberate Tate and the Art Not Oil Coalition, Museum \& Society 15(2) 126-41.

MARRIOTT, J. (2011) A Social License to Operate, Not if but when: Culture Beyond Oil, eds. M. Evans, G. Tarman, H. Newman, J. Clarke, and K. Smith, Art Not Oil, Liberate Tate, and Platform, London; 8-13.

McKEE, Y. (2007) Art and the Ends of Environmentalism: From Biosphere to the Right to Survival, Nongovernmental Politics, ed. M. Feher, with G. Krikorian and Y. McKee, Zone Books, New York; 539-83.

MEMOU, A. (2017) Art, Activism and the Tate, Third Text 31(5-6) 619-31.

MEYER, J. (2004) No More Scale: The Experience of Size in Contemporary Sculpture, Artforum International 42(10) 220-8.

MILES, M. (2000) Vistas of the Post-Industrial City, Advances in Art \& Urban Futures, Vol 1: Locality, Regeneration, and Divers[c]ities, eds. S. Bennett and J. Butler, Intellect, Bristol and Portland; 59-69.

MOORE, R., GETHINGS, S., eds. (1995) Tate Gallery of Modern Art: Selecting an Architect, Tate Gallery Publishing, London.

MOORE, R. (2000) Introduction, Building Tate Modern: Herzog \& De Meuron Transforming Giles Gilbert Scott, eds. R. Moore and R. Ryan, Tate Gallery, London; 7-12.

MOORE, R., RYAN, R., eds. (2000) Building Tate Modern: Herzog \& De Meuron Transforming Giles Gilbert Scott, Tate Gallery, London.

MOORE, R. (2005) Architecture in Motion, Tate Modern: The First Five Years, Tate Publishing, London; 29-32.

MOTION, J. (2019) Undoing Art and Oil: An Environmental Tale of Sponsorship, Cultural Justice and Climate Change Controversy, Environmental Politics 28(4) 727-46. 
MOUFFE, C. (2008) Art and Democracy: Art as Agnostic Intervention in Public Space, Open 14 6-15.

MOUFFE, C. (2013) Agonistics: Thinking the World Politically, Verso, London and New York.

NIXON, M., POTTS, A., FER, B., HUDEK, A., STALLABRASS, J. (2001) Round Table: Tate Modern, October 98(Fall) 3-25.

PLATFORM, ART NOT OIL, LIBERATE TATE (2011) About Us, Not if but when: Culture Beyond Oil, eds. M. Evans, G. Tarman, H. Newman, J. Clarke, and K. Smith, Art Not Oil, Liberate Tate, and Platform, London; 86-7.

RAUNIG, G., RAY, G., eds. (2009) Art and Contemporary Critical Practice: Reinventing Institutional Critique, MayFly, London.

RECTANUS, M.W. (2002) Corporate Cultural Politics: Corporate Identity and Culture, Culture Incorporated: Museums, Artists, and Corporate Sponsorships, University of Minnesota Press, Minneapolis and London; 22-58.

RECTANUS, M.W. (2016) Artists, Debt, and Global Activism, Finance and Society 2(1) 2-24.

RENDELL, J. (2006) Art and Architecture: A Place Between, I. B. Tauris, London and New York.

RYAN, R. (2000) Transformation, Building Tate Modern: Herzog \& De Meuron Transforming Giles Gilbert Scott, eds. R. Moore and R. Ryan, Tate Gallery, London; 13-36.

SALCEDO, D. (2007) Shibboleth.

SALTZMAN, L. (2006) Making Memory Matter: Strategies of Remembrance in Contemporary Art, The University of Chicago Press, Chicago and London.

SELF, R. (2014) The Architecture of the Art Museum: A Decade of Design, 20002010, Routledge, London and New York.

SEROTA, N. (2005) A New Landmark, Tate Modern: The First Five Years, ed. N. Serota, Tate Publishing, London; 5-6.

SKREBOWSKI, L. (2013) After Hans Haacke: Tue Greenfort and Ecoinstitutional Critique, Third Text 27(1) 115-30.

SMITH, R.H.C. (2005) The Political Impact, Tate Modern: The First Five Years, ed. N. Serota, Tate Publishing, London; 17-21.

STEYERL, H. (2012) The Articulation of Protest, Wretched of the Screen, eds. J. Aranda, B. K. Wood, A. Vidokle, Sternberg Press, Berlin; 77-91.

TRAVERS, T. (2005) Renewing London, Tate Modern: The First Five Years, ed. N. Serota, Tate Publishing, London; 23-8.

WEIWEI, A. (2010) Sunflower Seeds.

WHITEREAD, R. (1993) House.

WU, C-T. (2002) Privatizing Culture: Corporate Art Intervention Since the 1980s, Verso, London. 
Alınd1: 18.02.2019; Son Metin: 26.11.2019

Anahtar Sözcükler: mekâna-özgü sanat; eylemci performans sanatı; kurumsal eleştiri; müze mekânı; Liberate Tate.

\section{MEKÂNA-ÖZGÜ PROTESTO: LIBERATE TATE'İN TATE MODERN'DEKI PERFORMANSLARI}

Bu makale, Tate kurumlarının çok uluslu şirket BP ile sponsorluk anlaşmasını protesto etmek için Tate'in galeri mekânlarında protesto odaklı sanat çalışmaları yapan bir sanatçı topluluğu olan Liberate Tate'in mekâna-özgü performanslarını analiz etmektedir. Liberate Tate' in sanat çalışmalarının estetik, mekânsal, politik, sosyal ve ekolojik bileşenlerinin girift bir şekilde iç içe geçmekte olduğunu savunan bir çerçeve dahilinde, makale öncelikle sanat topluluğunun müdahale ettikleri alanlardan biri olan Tate Modern'deki Turbine Hall'un ve bu mekânda gerçekleşmiş olan performansların detaylı bir görsel analizini sunmaktadır. Bu görsel analize bağlı olarak, makale, sanatçı kolektifinin fiziksel mekânın sosyo-politik yapılanmasına kendi politik estetik tarzları içerisinde nasıl tepki verdiğini göstermektedir. Grubun mekâna-özgü eserlerinde dikkatli bir şekilde müze mekânını incelemelerinin ve bu kapsamda kuruma eleştirel bir şekilde karşı koymalarının boyutları öyle bir seviyeye gelmiştir ki, mekân Liberate Tate'in ana sanat aracı haline gelmiştir. Yatay düzenleme modelleri, dağınık, kirli ve yapışkan malzeme seçimleri ve doğaya, kültüre ve tarihe ayrılmaz kavramlar olarak yaklaşımları sayesinde Liberate Tate'in mekânaözgü gösterileri, Tate Modern'in egemen neoliberal söylemine meydan okumaktadır. Liberate Tate'in Turbine Hall'un görsel söylemine karşılık ortaya koyduğu karşıtlıklar ve çatışmalar, mekânın baskın siyasi, finansal ve sosyal düzenini ortaya çıkarmakta ve aynı zamanda müzeyi, geçici de olsa, gerçek bir kamusal demokrasi alanına dönüştürmektedir.

\section{SITE-SPECIFIC PROTEST: LIBERATE TATE'S PERFORMANCES AT TATE MODERN}

This paper analyzes the site-specific performances of Liberate Tate, an artist collective that staged protests at Tate galleries to oppose the institution's sponsorship deal with the multinational corporation BP. Arguing that the aesthetic, spatial, political, social, and ecological components of Liberate Tate's works are intricately enmeshed, the paper offers a close visual analysis of the performances in relation to one of their sites, Turbine Hall at Tate Modern. Doing so, the paper demonstrates how the artist collective reacted to the socio-political structuring of the physical space in their own political mode of aesthetics. The site-specific works of the group attend to and confront the museum space to such an extent that the intervened space becomes Liberate Tate's principal medium. Through their horizontal arrangement mode, choice of messy, dirty, and viscous materials, and approach to nature, culture, and history as inseparable concepts, Liberate Tate's site-specific performances challenge the hegemonic neoliberal rhetoric of Tate Modern. The contrasts and conflicts Liberate Tate introduces against the visual discourse of Turbine Hall not only reveals the dominant political, financial, and social order of the space but also transforms the museum albeit temporarily into a truly public space of democracy.

EKÍN PINAR; B.Arch., MA., PhD

Received her B.Arch. and MA. from Middle East Technical University. Earned her second MA. and PhD. degrees from the History of Art Department at the University of Pennsylvania. Research interests include history of modern and contemporary art and architecture, cinema studies, museum studies, and institutional critique.epinar@sas.upenn.edu 